\title{
Obstruktív alvási apnoéban szenvedő betegek jellemzői hazai beteganyagon
}

\author{
Bikov András dr. ${ }^{1,2}$. Mészáros Martina dr. ${ }^{1}$ - Kunos László dr. ${ }^{1,3}$ \\ ${ }^{1}$ Semmelweis Egyetem, Általános Orvostudományi Kar, Pulmonológiai Klinika, Budapest \\ ${ }^{2}$ Manchester University NHS Foundation Trust, Manchester, Egyesült Királyság \\ ${ }^{3}$ Törökbálinti Tüdőgyógyintézet, Törökbálint
}

Bevezetés és célkitüzés: Az obstruktív alvási apnoe (OSA) a felnőtt lakosság jelentős részét érintő betegség, mely ismert rizikófaktora a cardiovascularis és metabolicus betegségeknek és a korai halálozásnak. Mindazonáltal kevés magyarországi adat áll rendelkezésre az OSA-ban szenvedő betegek demográfiai és klinikai jellemzőiről, így vizsgálatunk célja ennek bemutatása volt.

Módszer: Retrospektív vizsgálatunkban a Semmelweis Egyetem Pulmonológiai Klinikájának Alváslaboratóriumában kivizsgált 394 személy (58 [46-66] év, 73\% férfi, testtömegindex [BMI] = 32,5 [29,2-37,5]) adatait elemeztük, akik kitöltötték az Epworth Álmosság Skálát, poliszomnográfiás vizsgálaton estek át; felvettük az anamnézist, és 255 esetben reggeli éhomi vérvétel történt.

Eredmények: 282 esetben igazolódott OSA. Ebben a csoportban magasabb volt a férfiak aránya (66 vs. 35\%), magasabb volt az életkor (59 [48-66] vs. 47 [39-60] év) és a BMI $(32,11[27,78-37,18]$ vs. 25,29 [22,04-29,03] kg/m²), magasabbak voltak a C-reaktív protein értékek $(3,0[1,71-5,34] \mathrm{mg} / 1$ vs. $1,71[0,91-3,31] \mathrm{mg} / 1)$, illetve a betegek gyakrabban szenvedtek társbetegségekben a kontrollcsoporthoz képest (magas vérnyomás 74\% vs. 39\%, cukorbetegség $24 \%$ vs. $11 \%$, dyslipidaemia $46 \%$ vs. $30 \%$, szív- és érrendszeri betegség $22 \%$ vs. $5 \%$, szívritmuszavar $27 \%$ vs. $16 \%$; minden $\mathrm{p}<0,05)$. Bár az OSA valószínűsége progresszívan nőtt az életkorral és az Epworth Álmosság Skála emelkedésével, a trendekben szignifikáns különbségeket észleltünk a férfiak és a nők között (mindkettő p<0,05). Ezzel szemben az OSA valószínúségének BMI-függése nemektől független volt $(\mathrm{p}=0,94)$.

Következtetés: Az OSA valószínúsége progresszívan emelkedik a kor, a BMI és a nappali aluszékonyság függvényében, ugyanakkor ezt befolyásolja a nem is. Közleményünk rámutat a társbetegségek szürésének fontosságára is az OSA különböző súlyossági fokaiban.

Orv Hetil. 2020; 161(50): 2117-2123.

Kulcsszavak: epidemiológia, obstruktív alvási apnoe, magasvérnyomás-betegség, cukorbetegség

\section{Characteristics of Hungarian patients with obstructive sleep apnoea}

Introduction and objective: Obstructive sleep apnoea (OSA) is a common disease which is a known risk factor for cardiovascular and metabolic disease and mortality as well. However, the demographic and clinical characteristics of Hungarian patients with OSA are less known. The aim of this study was to describe them.

Method: We analysed the data of 394 subjects (58 [46-66] years, 73\% male, body mass index [BMI] = 32.5 [29.237.5]) who attended the Sleep Laboratory of the Department of Pulmonology at Semmelweis University. The volunteers filled out the Epworth Sleepiness Scale, we performed a polysomnography and took medical history. In 255 subjects, fasting blood samples were collected.

Results: OSA was diagnosed in 282 cases. This group had higher proportion of males (66 vs. 35\%) and comorbidities (hypertension $74 \%$ vs. $39 \%$, diabetes $24 \%$ vs. $11 \%$, dyslipidaemia $46 \%$ vs. $30 \%$, cardiovascular diseases $22 \%$ vs. $5 \%$, arrhythmia $27 \%$ vs. $16 \%$ ), the patients were older (59 [48-66] vs. 47 [39-60] years) and had higher BMI (32.11 [27.78-37.18] vs. $\left.25.29[22.04-29.03] \mathrm{kg} / \mathrm{m}^{2}\right)$ and C-reactive protein levels $(3.0[1.71-5.34] \mathrm{mg} / 1 \mathrm{vs.} 1.71[0.91-$ $3.31] \mathrm{mg} / \mathrm{l}$, all $\mathrm{p}<0.05)$. There was a significant relationship between the propensity of OSA along increasing age, BMI and Epworth Sleepiness Scale; however, the relationship depended on gender for age and Epworth Sleepiness Scale (both $\mathrm{p}<0.05$ ).

Conclusion: The propensity of OSA increases with age, BMI and symptoms burden and it is affected by the gender. Our study highlights the importance of screening comorbidities in different severity grades of OSA.

Keywords: epidemiology, obstructive sleep apnoea, hypertension, diabetes

Bikov A, Mészáros M, Kunos L. [Characteristics of Hungarian patients with obstructive sleep apnoea]. Orv Hetil. 2020; 161(50): 2117-2123.

(Beérkezett: 2020. május 2.; elfogadva: 2020. július 11.) 


\section{Rövidítések}

AASM = (American Academy of Sleep Medicine) Amerikai Alvásmedicina Akadémia; $\mathrm{AHI}=$ apnoe-hypopnoe index; $\mathrm{AI}=$ (apnoea index) mikroébredés-index; BMI $=($ body mass index $)$ testtömegindex $; \mathrm{CPAP}=($ continuous positive airway pressure $)$ folyamatos pozitív nyomású légzéstámogatás; CRP = C-reaktív protein; ESS $=($ Epworth Sleepiness Scale $)$ Epworth Álmosság Skála; HDL = (high-density lipoprotein) magas sûrúségű lipoprotein; LDL = (low-density lipoprotein $)$ alacsony sűrüségú lipoprotein; ODI = oxigéndeszaturációs index; OECD = (Organisation for Economic Co-operation and Development) Gazdasági Együttmúködési és Fejlesztési Szervezet; OSA = (obstructive sleep apnoea) obstruktív alvási apnoe; TST = (total sleep time) teljes alvásidő

Az obstruktív alvási apnoe (OSA) a garat alvás közbeni, ismétlődő, részleges vagy teljes kollapszusával jellemezhetố betegség, melyhez krónikus intermittáló hypoxia és gyakori mikroébredések társulnak. A betegséget éjszakai (horkolás, légzéskimaradások) és nappali (álmosság, a koncentráció hiánya, a teljesítmény csökkenése stb.) tünetek jellemzik. Emellett jól ismert, hogy az OSA-hoz gyakran kapcsolódnak cardiovascularis és metabolicus betegségek [1] és a középsúlyos-súlyos OSA a korai mortalitás független rizikója [2].

Az OSA gyakorisága világszerte nagyon magas [3]. Ismert, hogy a betegség gyakoribb férfiakban, a prevalencia nő az életkorral és a testtömegindexszel (BMI), és egyes csoportokban a betegség előfordulása akár az 50\%ot is elérheti [3,4]. Egy 2019-ben publikált összefoglaló közlemény szerint az OSA becsült gyakorisága Magyarországon a felnőtt lakosság körében 38,6\%, ami megközelítőleg 2,1 millió beteget jelent [3]. Fontos hangsúlyozni, hogy a Gazdasági Együttmúködési és Fejlesztési Szervezet (OECD) felmérései alapján a magyar lakosság a többi európai országhoz képest is elhízott [5], ezért a $38,6 \%$ valószínúleg alulbecsült érték. Érdekes, hogy a fenti arány nagyon hasonló Torzsa és mtsai 2010 előtt végzett, kérdőíven alapuló epidemiológiai vizsgatához, amelynek során a magyar férfilakosság $37 \%$-a, a nők $21 \%$-a panaszolt hangos horkolást légzésszünetekkel [6]. Tekintettel arra, hogy a magyar társadalomban az elhízás gyakorisága azóta emelkedett [7], az OSA becsült gyakorisága 40-50\% lehet.

Az OSA és a magasvérnyomás-betegség, a cardiovascularis megbetegedések, a szívritmuszavarok, a cukorbetegség és a zsíranyagcsere zavarai közötti kapcsolat jól ismert [8]. Ugyanakkor tény, hogy a kapcsolat nem egyenesen arányos a betegség súlyosságával, hiszen sok faktor befolyásolja, mint a nem, az elhízás mértéke, az étrend, a dohányzás és számos genetikai faktor [9]. Emiatt Magyarországon a fenti társbetegségek prevalenciája OSA-ban feltehetóen eltér a külföldi publikációkban közöltekétől, ugyanakkor hazánkban nem áll rendelkezésre kellő adat.
1. táblázat $\mid$ Az obstruktív alvási apnoe gyanújával beutalt betegek demográfiai jellemzői és alvásparaméterei

\begin{tabular}{lc}
\hline Az OSA gyanújával beutalt betegek jellemzői & \\
\hline Kor (év) & $58(46-66)$ \\
Nem $(f e ́ r f \%)$ & 73 \\
BMI $\left(\mathrm{kg} / \mathrm{m}^{2}\right)$ & $32,5(29,2-37,5)$ \\
ESS & $6(3-8)$ \\
Kifejezett nappali álmosság (ESS>10,\%) & 13 \\
Magas vérnyomás (\%) & 75 \\
Cukorbetegség (\%) & 25 \\
Dyslipidaemia (\%) & 41 \\
Szív- és érrendszeri megbetegedések (\%) & 20 \\
Szívritmuszavarok (\%) & 28 \\
TST (perc) & $420,0(385,0-457,8)$ \\
AHI (1/óra) & $23,9(11,8-43,8)$ \\
ODI (1/óra) & $20,8(9,4-38,0)$ \\
AI (1/óra) & $39,6 \pm 21,0$ \\
OSA (\%) & 89 \\
Kontroll/Enyhe/középsúlyos/súlyos OSA & $11 / 18 / 29 / 42$ \\
(\%) & \\
\hline
\end{tabular}

AHI = apnoe-hypopnoe index; AI = mikroébredés-index; BMI = testtömegindex; ESS = Epworth Álmosság Skála; ODI = oxigéndeszaturációs index; OSA = obstruktív alvási apnoe; TST = teljes alvásidő

Leíró vizsgálatunk célja a magyar OSA-betegek demográfiai és klinikai adatainak, illetve komorbiditásprofiljának elemzése és bemutatása volt.

\section{Módszer}

\section{Vizsgálati protokoll és módszerek}

A vizsgálatban a Semmelweis Egyetem Pulmonológiai Klinikájára OSA gyanújával beutalt betegek $(\mathrm{n}=253$, 1. táblázat) és az alvás-ikervizsgálatban [10] részt vevő önkéntesek $(n=141)$ adatait elemeztük. A vizsgálat estéjén részletes anamnézisfelvételt követően a résztvevők kitöltötték az Epworth Álmosság Skála (ESS) magyar változatát, majd poliszomnográfiát végeztünk. A vizsgálat estéjén $(\mathrm{n}=195)$ és másnap reggel $(\mathrm{n}=255)$ opcionális vérnyomásmérés és vérvétel történt biomarkerek meghatározására. A reggeli éhomi vérvétel során meghatározásra került a C-reaktív protein (CRP) szintje, a lipidprofil (összkoleszterin, LDL-koleszterin, HDL-koleszterin, triglicerid) és a vércukorszint is.

A komorbiditásokat a hazai és a nemzetközi irányelvek szerint definiáltuk. Ehhez segítséget a beteg anamnézise és gyógyszerei, a vérnyomásmérés és a vérvétel eredményei jelentettek. Bizonytalan esetben szakorvosi referálás történt a diagnózis tisztázására. Szív- és érrendszeri megbetegedéseken cardiovascularis (stabil és instabil angina) és cerebrovascularis (átmeneti ischaemiás roham, stroke) betegségeket értettünk. Szívritmuszavarokon 
pitvarfibrillációt és egyéb supraventricularis tachycardiákat értettünk.

A vizsgálatokat a Semmelweis Egyetem Regionális, Intézményi Tudományos és Kutatásetikai Bizottsága hagyta jóvá $(30 / 2014$ és 172/2018). Az önkéntesek a vizsgálatokba írásos beleegyezésüket adták.

\section{Alvásvizsgálat}

Az önkénteseknél poliszomnográfia (SOMNOscreen plus Tele PSG, SOMNOmedics GmbH, Randersacker, Németország) történt, melynek során elektroencefalogram, elektrookulogram, elektromiogram, mellkasi és légzőmozgás, légzési hangok, nasalis nyomás, elektrokardiogram és oxigénszaturáció került regisztrálásra az Amerikai Alvásmedicina Akadémia (AASM) aktuális irányelvei szerint [11]. Az alvásfázisokat, mozgásokat és légzési eseményeket az AASM irányelvei szerint értékeltük [12]. Apnoén 10 másodpercet meghaladó, legalább 90\%-os nasalis légnyomáscsökkenést értettünk, a hypopnoe definiálásához 10 másodpercet meghaladó, legalább 30\%-os nasalis légnyomáscsökkenést használtunk, melyhez legalább 3\%-os deszaturáció vagy mikroébredés társult. Rögzítettük a teljes alvásidőt (TST), kiszámításra került az apnoe-hypopnoe index (AHI), az oxigéndesza- turációs index (ODI) és a mikroébredés-index (AI). Ezek alapján az önkénteseket OSA- (AHI $\geq 5$ /óra) és kontrollcsoportba soroltuk be. Az OSA-csoportot enyhe (AHI 5-14,9/óra), középsúlyos (AHI 15-29,9/óra) és súlyos (AHI $\geq 30 /$ óra) csoportra osztottuk.

\section{Statisztikai analizis}

A GraphPad Prism 5.0 (GraphPad Software, San Diego, CA, USA) statisztikai programot használtuk az analízishez. Az adatok normalitását Kolmogorov-Szmirnovteszttel vizsgáltuk. Az OSA- és a kontrollcsoportot tpróbával, Mann-Whitney-teszttel és khi-négyzet-teszttel hasonlítottuk össze. Az OSA valószínúségének a kortól, a BMI-tôl és az ESS-tôl való függését Mantel-Cox-teszttel hasonlítottuk össze a férfiak és a nők között és az OSA három súlyossági foka között. Az önkénteseket nappali aluszékonyságot mutató (ESS>10) és nem mutató $(\mathrm{ESS} \leq \mathrm{ll})$ csoportra osztottuk. A nappali aluszékony csoport AHI-függését logisztikus regresszióval vizsgáltuk, melyet korra, nemre és BMI-re súlyoztunk. Az adatokat normális eloszlás esetén átlag \pm szórásként, nemparametrikus eloszlás esetén medián (interkvartilis tartományként) adtuk meg. A p<0,05 értéket tekintettük szignifikánsnak.

2. táblázat |Az obstruktív alvási apnoéban szenvedő és a kontrollcsoport demográfiai jellemzői és alvásparaméterei

\begin{tabular}{|c|c|c|c|}
\hline & OSA $(n=282)$ & Kontroll $(\mathrm{n}=112)$ & $\mathrm{p}$ \\
\hline Kor (év) & $59(48-66)$ & $47(39-60)$ & $<0,01$ \\
\hline Nem (férfi\%) & 66 & 35 & $<0,01$ \\
\hline BMI $\left(\mathrm{kg} / \mathrm{m}^{2}\right)$ & $32,11(27,78-37,18)$ & $25,29(22,04-29,03)$ & $<0,01$ \\
\hline ESS & $6,0(3,0-8,0)$ & $6,0(3,0-8,5)$ & 0,47 \\
\hline Magas vérnyomás (\%) & 74 & 39 & $<0,01$ \\
\hline Cukorbetegség (\%) & 24 & 11 & $<0,01$ \\
\hline Dyslipidaemia (\%) & 46 & 30 & $<0,01$ \\
\hline Szív- és érrendszeri megbetegedések (\%) & 22 & 5 & $<0,01$ \\
\hline Szívritmuszavarok (\%) & 27 & 16 & 0,02 \\
\hline $\mathrm{CRP}(\mathrm{mg} / \mathrm{ml})$ & $3,0(1,71-5,34)$ & $1,71(0,91-3,31)$ & $<0,01$ \\
\hline Triglicerid (mmol/l) & $1,62(1,20-2,18)$ & $1,15(0,86-1,62)$ & $<0,01$ \\
\hline Összkoleszterin $(\mathrm{mmol} / \mathrm{l})$ & $5,3(4,4-6,1)$ & $5,3(4,8-6,2)$ & 0,25 \\
\hline HDL-koleszterin $(\mathrm{mmol} / \mathrm{l})$ & $1,25(1,05-1,49)$ & $1,62(1,36-2,05) /$ & $<0,01$ \\
\hline LDL-koleszterin $(\mathrm{mmol} / \mathrm{l})$ & $3,24 \pm 1,09$ & $3,20 \pm 1,04$ & 0,77 \\
\hline Vércukor (mmol/l) & $5,3(4,8-6,4)$ & $4,7(4,3-5,1)$ & $<0,01$ \\
\hline Vércukor a cukorbetegségben nem szenvedők körében ( $\mathrm{mmol} / \mathrm{l})$ & $5,1(4,7-5,4)$ & $4,7(4,3-5,0)$ & $<0,01$ \\
\hline TST (perc) & $415,3(381,9-444,6)$ & $391,5(349,8-420,4)$ & $<0,01$ \\
\hline AHI (1/óra) & $22,7(12,3-42,4)$ & $2,2(1,1-3,1)$ & $<0,01$ \\
\hline ODI (1/óra) & $19,4(9,5-35,6)$ & $1,0(0,4-2,0)$ & $<0,01$ \\
\hline AI (1/óra) & $43,3(29,9-58,9)$ & $48,2(33,7-57,0)$ & 0,9 \\
\hline
\end{tabular}

$\mathrm{AHI}=$ apnoe-hypopnoe index; $\mathrm{AI}=$ mikroébredés-index $; \mathrm{BMI}=$ testtömegindex $; \mathrm{CRP}=\mathrm{C}$-reaktív protein; ESS = Epworth Álmosság Skála; HDL = magas denzitású lipoprotein $; \mathrm{LDL}=$ alacsony denzitású lipoprotein; $\mathrm{ODI}=$ oxigéndeszaturációs index; OSA = obstruktív alvási apnoe; TST = teljes alvásidő 


\section{Eredmények}

\section{Az OSA-és a kontrollcsoport demográfiai jellemzôi és alvásparaméterei}

A csoportok adatait és összehasonlítását a 2. táblázat tartalmazza. Összefoglalva, az OSA-betegek idősebbek voltak, magasabb volt a BMI-jük, CRP-, triglicerid- és vércukorszintjük, alacsonyabb volt a HDL-koleszterin-értékük, és magasabb volt közöttük a férfiak és a társbetegségek aránya. Az OSA-csoportban magasabb volt az AHI- és az ODI-érték, illetve hosszabb volt a teljes alvásidő (minden $\mathrm{p}<0,05$ ). Érdekesség, hogy a csoportok között nem volt különbség az ESS-ben, illetve az ébredési indexben ( $p>0,05)$.

\section{Az OSA valószinüségének kor-, BMI- és ESS-függése férfiakban és nökben}

Az OSA valószínűsége szignifikánsan összefüggött az életkorral ( $1 / A$ ábra). Ugyanakkor az összefüggés szignifikánsan szorosabb volt a férfiak körében $(\mathrm{p}<0,01)$. A nőknél az OSA-valószínúség 50 éves életkor után kezdett meredeken emelkedni. Az OSA valószínúsége szignifikánsan összefüggött a BMI-vel, ugyanakkor nem találtunk különbséget a férfiak és a nők között ( $\mathrm{p}=0,94$, $1 / B$ ábra). Az OSA valószínüsége növekedett az ESS emelkedésével ( $1 / C$ ábra), a növekedés üteme pedig szignifikánsan eltért a férfiakban és a nókben $(\mathrm{p}=0,02)$.

Amikor az OSA különböző súlyossági fokozatainak valószínúségét elemeztük a kor, a BMI és az ESS függvényében, a három csoport között a különbség mindhá- rom analízist tekintve szignifikánsnak bizonyult $(\mathrm{p}<0,01$, 2. ábra).

A nappali aluszékonyság és az AHI között laza, de szignifikáns összefüggést találtunk $(\beta=0,02, p<0,01)$, mely független volt a nemtől, a kortól és a BMI-től.

\section{A komorbiditási profil OSA-ban}

A magasvérnyomás-betegség, a cukorbetegség, a dyslipidaemia, a szív- és érrendszeri betegségek és a szívritmuszavar fennállása szignifikánsan gyakoribb volt OSA-ban (2. táblázat).

A magasvérnyomás-betegség $(\mathrm{p}<0,01)$ és a cukorbetegség $(\mathrm{p}=0,01)$ valószínúsége progresszívan emelkedett az OSA súlyosságával. A dyslipidaemia $(\mathrm{p}=0,04)$ és a szív- és érrendszeri megbetegedések $(\mathrm{p}<0,01)$ valószínüsége már enyhe OSA esetén is magasabb volt, és nem mutatott változást a súlyosság fokozódásával. A szívritmuszavar valószínúsége középsúlyos és súlyos OSA-betegeknél volt a legmagasabb $(\mathrm{p}=0,03,3$. táblázat $)$.

\section{Megbeszélés}

Vizsgálatunkban a Semmelweis Egyetem Pulmonológiai Klinikájának Alváslaboratóriumában 2014-től zajló tudományos vizsgálatokban részt vevő önkéntesek adatait elemeztük. A vizsgált személyeket a beutalt betegek köréből és egy ikervizsgálat során toboroztuk. Az ikervizsgálat eredményeit a korábbiakban publikáltuk [10]. Kiemelendő, hogy az utóbbi csoportban az OSA gyakorisága $41 \%$ volt, ami megfelel egy metaanalízisben becsült magyarországi prevalenciának [3]. A beutalt bete-
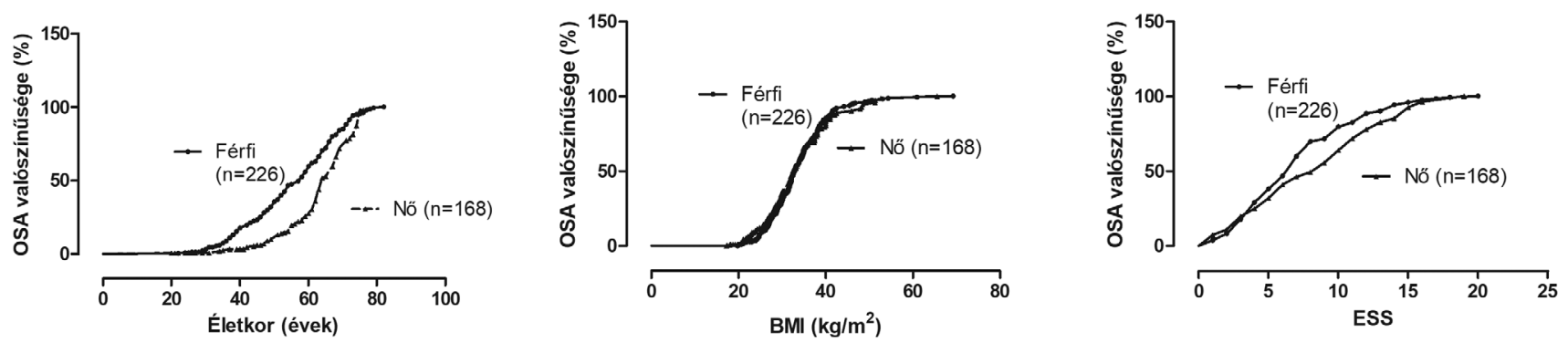

1. ábra Az obstruktív alvási apnoe valószínúsége az életkor, a BMI és az ESS függvényében férfiakban és nőkben BMI = testtömegindex; ESS = Epworth Álmosság Skála; OSA = obstruktív alvási apnoe
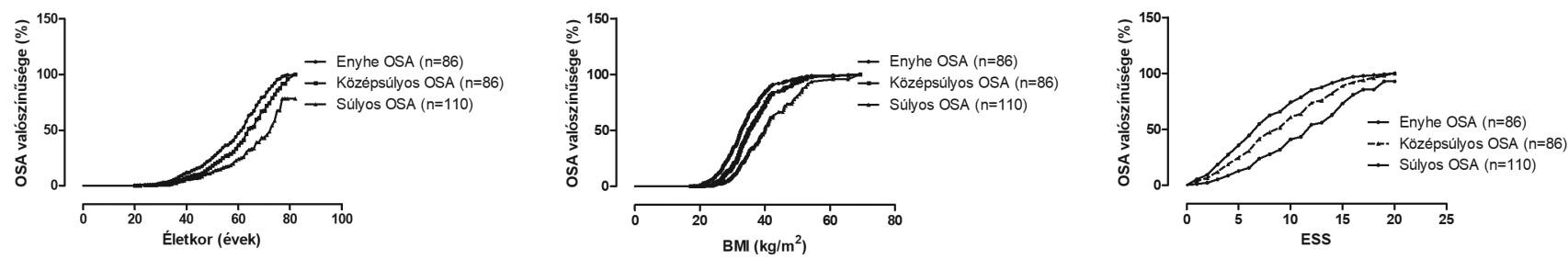

\begin{tabular}{l|l} 
2. ábra & $\begin{array}{l}\text { Az obstruktív alvási apnoe súlyossági fokozatainak valószínúsége az életkor, a BMI és az ESS függvényében } \\
\text { BMI = testtömegindex; ESS = Epworth Álmosság Skála; OSA = obstruktív alvási apnoe }\end{array}$
\end{tabular} 
3. táblázat |A társbetegségek előfordulási gyakorisága az obstruktív alvási apnoe különböző súlyossági fokozataiban

\begin{tabular}{lcccc}
\hline & $\begin{array}{c}\text { Kontroll } \\
(\mathrm{n}=112)\end{array}$ & $\begin{array}{c}\text { Enyhe OSA } \\
(\mathrm{n}=86)\end{array}$ & $\begin{array}{c}\text { Középsú- } \\
\text { lyos OSA } \\
(\mathrm{n}=86)\end{array}$ & $\begin{array}{c}\text { Súlyos } \\
\text { OSA } \\
(\mathrm{n}=110)\end{array}$ \\
\hline Magas vérnyomás (\%) & 39 & 65 & 77 & 79 \\
Cukorbetegség (\%) & 11 & 19 & 23 & 28 \\
Dyslipidaemia (\%) & 30 & 49 & 45 & 44 \\
Szív- és érrendszeri & 5 & 26 & 24 & 18 \\
megbetegedések (\%) & & & & 30 \\
Szívritmuszavarok (\%) & 16 & 20 & 30 & 30 \\
\hline
\end{tabular}

OSA = obstruktív alvási apnoe

gek körében az OSA gyakorisága 89\% volt, és a betegek 71\%-a középsúlyos és súlyos OSA-ban szenvedett. A beutalt betegek túlnyomó része obes $\left(\mathrm{BMI} \geq 30 \mathrm{~kg} / \mathrm{m}^{2}\right)$ volt, és jellemzően társbetegségekben szenvedett. Érdekesség, hogy a betegek mindössze 13\%-a panaszolt nappali aluszékonyságot. Egy európai multicentrikus vizsgálatban az aluszékonyság gyakorisága 44\%-nak adódott OSA esetén [13], így a vizsgálatunkban tapasztalt arány meglepően alacsony. Ennek hátterében több tényező is állhat. Egyrészt az aluszékonyság mértékét az Epworthkérdőívvel rögzítettük, amelynél a betegeknek arra kell reflektálniuk, hogy különböző élethelyzetekben milyen valószínúséggel alszanak el [14]. A leírt élethelyzeteket a betegek szubjektíven értékelik, és előfordul, hogy a kérdéseket nehezen értelmezik. Például az „Autóban utasként, közel egyórás megszakítás nélküli út után” kérdésre, amennyiben a beteg nem szokott autóban utasként utazni, a válasz sokszor „nem álmosodom el”. Az OSA progresszív betegség, hosszú fennállás esetén a betegek megszokják a tüneteiket, azokat normálisnak tekintik, így az adott kérdésre (például „olvasás, pihenés közben”) sokszor alacsony („nem álmosodom el”) pontszámot adnak. Mindezek mellett a vizsgálatunkban mért alacsony pontszám hátterében felmerül annak valószínüsége, hogy a betegek tudatosan alacsony, a valós állapotot nem tükröző pontszámokat adtak meg, hiszen a kifejezett nappali aluszékonyság a munkavégzésükre és a jogosítványukra is negatív következménnyel járhat [15]. Bár az ESS és az OSA súlyossága között csak laza összefüggés áll fenn [16], az OSA valószínúsége vizsgálatunkban az ESS növekedésével nőtt.

Várakozásainknak megfelelően az OSA-csoportban több volt a férfi, az OSA-ban szenvedőknek magasabb volt az életkoruk, a BMI-értékük, és gyakoribbak voltak körükben a társbetegségek. Jól ismert, hogy az OSA gyakoribb férfiakban, aminek hátterében a női hormonok protektív szerepe áll [17]. Vizsgálatunkban az OSA valószínúségét az életkor, a BMI és az ESS függvényében hasonlítottuk össze férfiak és nők között. A hormonális protektív tényezők szerepét jól jelzi, hogy míg férfiakban 35 éves életkor felett az életkor előrehaladásával az OSA valószínúsége folyamatosan nőtt, addig nőknél ezt a nö- vekedést csak a menopauza után észleltük. Fontos kiemelni azonban, hogy az OSA valószínúségének és a BMI értékének az összefüggésében nem volt különbség a nemek között. Ez arra utal, hogy az életkorhoz és a nemhez képest a BMI növekedése sokkal szorosabban függ össze az OSA kialakulásának veszélyével. Ez különösen fontos a klinikai gyakorlat szempontjából, mivel a demográfiai paraméterekkel ellentétben a BMI aktívan befolyásolható $[18,19]$. A testsúlycsökkentés azért is fontos, mert bizonyítottan csökkenti a cardiometabolicus morbiditást és mortalitást, ezért obes OSA-betegek kezelésekor a CPAP mellett mindenképpen javasolt a testsúlycsökkentés szorgalmazása [18]. Összehasonlítva az OSA valószínúségének ESS-függését, szignifikáns különbséget tapasztaltunk a férfiak és a nők között. Jól ismert, hogy a férfiak és a nők különböző tünetekről számolnak be OSA-ban, aminek hátterében az eltérő percepció, a tünetekről való beszámolás hajlandósága (a nők egy része szégyelli a horkolást) és élettani okok (például eltérő ébredési küszöb) állnak [17]. Vizsgálatunk egyik limitációjaként említendő, hogy a kontrollcsoportban jóval nagyobb volt a női nem előfordulásának aránya, ami befolyásolhatta a nemek közti összehasonlítást az OSA- és a kontrollcsoport között.

Az OSA és a komorbiditások kapcsolata jól ismert. Ennek hátterében OSA-hoz köthető (intermittáló hypoxia, emelkedett szimpatikus tónus, alvásfragmentáció, hormonális változások) és közös etiológiai faktorok (nem, kor, BMI) állnak. Vizsgálatunkban OSA-ban minden vizsgált társbetegség magasabb arányban volt jelen a kontrollcsoporthoz képest. Megemlítendő, hogy az OSA-csoport résztvevői jóval idősebbek voltak az egészséges résztvevőknél, így ez befolyásolhatta a társbetegségek előfordulási gyakoriságát a két csoportban. Vizsgálatunk limitált esetszáma miatt érdemes adatainkat a komorbiditások epidemiológiai vizsgálatokban becsült arányaihoz hasonlítani. Az OECD felmérésében Magyarországon a magasvérnyomás-gyógyszert szedők aránya 56\%, a lipidcsökkentő gyógyszert szedőké 11\% [5]. Vizsgálatunkban markáns különbséget észleltünk az OSA- (74\%) és a kontrollcsoport (39\%) között a magasvérnyomás-betegség prevalenciájában. Az OECD által leírt arány a kettő középértéke, ami arra utal, hogy a hypertoniások között sok az OSA-beteg. Emellett fontos megjegyezni, hogy a terápiára rezisztens magas vérnyomásban szenvedőkben az OSA előfordulása különösen magas, akár a 80\%-ot is elérheti [20]. Sokkal érdekesebb, hogy jelentősen magasabb arányban észleltünk lipideltéréseket mind az OSA-, mind a kontrollcsoportban. A dyslipidaemia definiálásakor a korábban diagnosztizált betegség mellett a vizsgálat közben levett éhomi laboreredményeket vettük figyelembe [21], ami a gyógyszeres kezelést igénylő dyslipidaemiákhoz képest magasabb találati arányt adott. A cukorbetegség hazai prevalenciája 7,6\% [5], ami arányaiban megegyezett a kontrollcsoportéval. Vizsgálatunkban OSA-ban háromszor gyakrabban $(24 \%)$ fordult elő cukorbetegség, ami kiemeli a cu- 
korbetegség szűrésének fontosságát OSA igazolása esetén. Világszerte a felnőtt lakosság 6\%-a szenved koszorúér-betegségben, további $3 \%$ agyérbetegségben, kb. 10-15\% szívritmuszavarban [22]. Ezek az arányok megegyeztek a vizsgálatunk kontrollcsoportjában detektált arányokkal. Fontos kiemelni, hogy vizsgálatunkba elsősorban olyan betegek kerültek bevonásra, akiket OSA gyanúja miatt utaltak Klinikánkra. A gyanú alapját sok esetben képezte ritmuszavar vagy szív- és érrendszeri megbetegedés, ami miatt a kontrollcsoportban a mért arányok felülreprezentáltak. Korábban leírtuk, hogy minimálisan tünetes OSA-betegekben, akiknek nem volt ismert cardiovascularis megbetegedésük, a kalcifikált koszorúérplakkokkal rendelkező személyek aránya 44\% volt, míg további 36\%-ban találtunk nem kalcifikált plakkokat [23]. Ugyanezen arányok nem OSA-beteg kontrolloknál 21\%-nak és 11\%-nak adódtak [23]. A vizsgálatunkban OSA-ban jelzett 22\%-os megbetegedési arány így valószínúleg csak a jéghegy csúcsa.

Ismert, hogy a középsúlyos és súlyos OSA a mortalitás független rizikófaktora [2]. Vizsgálatunkban emiatt az OSA-csoportot három alcsoportra bontottuk. Várakozásunknak megfelelően az OSA fokozott súlyosságának valószínúsége az életkor, a BMI és az ESS függvényében egyre kifejezettebbé vált. A 2. ábra rámutat, hogy a nappali aluszékonyságot panaszolóknál (ESS>10) és középsúlyos elhízásban $\left(\mathrm{BMI} \geq 35 \mathrm{~kg} / \mathrm{m}^{2}\right)$ már 50\%-os valószínûséggel igazoltunk középsúlyos-súlyos OSA-t. Ezért ezeknél a betegeknél különösen megfontolandó alvásvizsgálat végzése OSA irányában. A magasvérnyomásbetegség, a cukorbetegség és a szívritmuszavar gyakorisága szignifikáns összefüggést mutatott az OSA súlyosságával. Ez arra utalhat, hogy az intermittáló hypoxia által okozott károsodás közvetlenül vezethet a komorbiditások kialakulásához. Érdekesség, hogy a dyslipidaemia gyakorisága és az OSA súlyossága között nem állt fenn kimutatható, direkt kapcsolat. Ez a megfigyelés egybecseng egy multicentrikus európai vizsgálat adataival [24]. Elképzelhető, hogy a súlyosan obes OSA-betegek tudatosabb életmódot folytattak diétával és testedzéssel, ugyanakkor az életmódot jellemző adatok nem állnak rendelkezésünkre. Már enyhe OSA-ban is magasabb gyakorisággal fordult elő szív- és érrendszeri megbetegedés, ugyanakkor a súlyosság emelkedésével nem nőtt ezen betegségek prevalenciája. A korábbi vizsgálatok szerint az OSA súlyosságával magasabb arányban fordult elö infarktus és stroke, illetve magasabb volt a cardiovascularis halálozás kockázata [25]. Elképzelhető, hogy az érelmeszesedés kialakulásához az OSA-val közös etiológiájú faktorok (nem, kor, BMI) járulnak hozzá, ugyanakkor az akut események fellépéséhez hozzájárul az obstruktív légzési események gyakorisága. Fontos megemlíteni, hogy a szisztémás gyulladás kiemelkedő szerepet tölt be az OSA-val asszociált társbetegségek, így a szív- és érrendszeri betegségek, az érelmeszesedés és a dyslipidaemia kórélettanában. A szisztémás gyulladás legáltalánosabb jelzője a CRP. Korábbi kutatásokhoz ha- sonlóan a CRP-szintek vizsgálatunkban is szignifikánsan magasabbnak bizonyultak az OSA-ban szenvedő résztvevők körében a kontrollcsoporthoz képest [26]. A CRP mellett számos proinflammatorikus citokin és biomarker (például adhéziós molekulák, komplementek) magasabb szintjét igazolták OSA-ban [27, 28].

Tudomásunk szerint hazánkban korábban nem publikáltak hasonló részletességú közleményt az OSA-betegek demográfiai és klinikai jellemzőiről. Vizsgálatunk rámutat bizonyos populációkban az OSA különösen magas gyakoriságára, emellett felhívja a figyelmet a komorbiditások OSA-betegeknél tapasztalható gyakoriságára. Mindezek miatt fontos, hogy meglévő kockázati faktorok, illetve társbetegségek esetén vizsgáljuk az OSA fennállását, illetve OSA diagnózisa esetén gondoljunk a társbetegségek lehetőségére, és törekedjünk azok aktív szürésére és kezelésére.

Anyagi támogatás: A vizsgálatokat a Magyar Tüdőgyógyász Társaság (Bikov András és Mészáros Martina részére) és a Semmelweis Egyetem (Klinikus Kutatói Ösztöndíj Kunos László részére) támogatta. Bikov András a vizsgálat során a Magyar Tudományos Akadémia Bolyai János Kutatási Ösztöndíjában és az NIHR Manchester BRC támogatásában részesült.

Szerzői munkamegosztás: A vizsgálatot B. A. és K. L. tervezte. B. A. és K. L. részt vett az alvásvizsgálatok eredményeinek elemzésében. B. A. és M. M. statisztikai elemzéseket végzett. A kéziratot B. A. készítette. A közlemény végleges változatát valamennyi szerző elolvasta és jóváhagyta.

Érdekeltségek: A szerzőknek nincsenek érdekeltségeik.

\section{Irodalom}

[1] Drager LF, Togeiro SM, Polotsky VY, et al. Obstructive sleep apnea: A cardiometabolic risk in obesity and the metabolic syndrome. J Am Coll Cardiol. 2013; 62: 569-576.

[2] Marshall NS, Wong KK, Cullen SR, et al. Sleep apnea and 20year follow-up for all-cause mortality, stroke, and cancer incidence and mortality in the Busselton Health Study cohort. J Clin Sleep Med. 2014; 10: 355-362.

[3] Benjafield AV, Ayas NT, Eastwood PR, et al. Estimation of the global prevalence and burden of obstructive sleep apnoea: a literature-based analysis. Lancet Respir Med. 2019; 7: 687-698.

[4] Peppard PE, Young T, Barnet JH, et al. Increased prevalence of sleep-disordered breathing in adults. Am J Epidemiol. 2013; 177: 1006-1014.

[5] OECDiLibrary. Health at a glance 2019: OECD indicators. OECD Publishing, Paris, 2019. https://doi.org/10.1787/ 4dd50c09-en. Available from: https://www.oecd-ilibrary.org [accessed: April 1, 2020].

[6] Torzsa P, Keszei A, Kalabay L, et al. Socio-demographic charac teristics, health behaviour, co-morbidity and accidents in snorers: a population survey. Sleep Breath 2011; 15: 809-818.

[7] Rurik I, Ungvári T, Szidor J, et al. Obese Hungary. Trend and prevalence of overweight and obesity in Hungary, 2015. [Elhízó Magyarország. A túlsúly és az elhízás trendje és prevalenciája 
Magyarországon, 2015.] Orv Hetil. 2016; 157: 1248-1255. [Hungarian]

[8] Gottlieb DJ, Punjabi NM. Diagnosis and management of obstructive sleep apnea: a review. JAMA 2020; 323: 1389-1400.

[9] Mészáros M, Tárnoki ÁD, Tárnoki DL, et al. Obstructive sleep apnea and hypertriglyceridaemia share common genetic background: Results of a twin study. J Sleep Res. 2020: e12979.

[10] Szily M, Tárnoki AD, Tárnoki DL, et al. Genetic influences on the onset of obstructive sleep apnoea and daytime sleepiness: a twin study. Respir Res. 2019; 20: 125.

[11] Kushida CA, Littner MR, Morgenthaler T, et al. Practice parameters for the indications for polysomnography and related procedures: an update for 2005. Sleep 2005; 28: 499-521.

[12] Berry RB, Budhiraja R, Gottlieb DJ, et al. Rules for scoring respiratory events in sleep: update of the 2007 AASM Manual for the Scoring of Sleep and Associated Events. Deliberations of the Sleep Apnea Definitions Task Force of the American Academy of Sleep Medicine. J Clin Sleep Med. 2012; 8: 597-619.

[13] Saaresranta T, Hedner J, Bonsignore MR, et al. Clinical phenotypes and comorbidity in European sleep apnoea patients. PLoS ONE 2016; 11: e0163439.

[14] Johns MW. A new method for measuring daytime sleepiness: the Epworth Sleepiness Scale. Sleep 1991; 14: 540-545.

[15] Szakács Z, Ádám Á, Annus JK, et al. Hungarian Society for Sleep Medicine guideline for detecting drivers with obstructive sleep apnea syndrome. [A Magyar Alvásdiagnosztikai és Terápiás Társaság módszertani ajánlása a közúti jármúvezetők egészségi alkalmasságának vizsgálatához az obstruktív alvási apnoe szindróma vonatkozásában.] Orv Hetil. 2016; 157: 892-900. [Hungarian]

[16] Chiu HY, Chen PY, Chuang LP, et al. Diagnostic accuracy of the Berlin questionnaire, STOP-BANG, STOP, and Epworth Sleepiness Scale in detecting obstructive sleep apnea: a bivariate metaanalysis. Sleep Med Rev. 2017; 36: 57-70.

[17] Lin CM, Davidson TM, Ancoli-Israel S. Gender differences in obstructive sleep apnea and treatment implications. Sleep Med Rev. 2008; 12: 481-496.

[18] Joosten SA, Hamilton GS, Naughton MT. Impact of weight loss management in OSA. Chest 2017; 152: 194-203.
[19] Tham KW, Lee PC, Lim CH. Weight management in obstructive sleep apnea: medical and surgical options. Sleep Med Clin. 2019; 14: 143-153

[20] Logan AG, Perlikowski SM, Mente A, et al. High prevalence of unrecognized sleep apnoea in drug-resistant hypertension. J Hypertens. 2001; 19: 2271-2277.

[21] Grundy SM, Cleeman JI, Daniels SR, et al. Diagnosis and management of the metabolic syndrome: an American Heart Association/National Heart, Lung, and Blood Institute Scientific Statement. Circulation 2005; 112: 2735-2752.

[22] Mozaffarian D, Benjamin EJ, Go AS, et al. Executive summary: heart disease and stroke statistics - 2016 update. A report from the American Heart Association. Circulation 2016; 133: 447454.

[23] Bikov A, Kolossváry M, Jermendy AL, et al. Comprehensive coronary plaque assessment in patients with obstructive sleep apnea. J Sleep Res. 2019; 28: e12828.

[24] Gündüz C, Basoglu OK, Hedner J, et al. Obstructive sleep apnoea independently predicts lipid levels: data from the European Sleep Apnea Database. Respirology 2018; 23: 1180-1189.

[25] Kendzerska T, Gershon AS, Hawker G, et al. Obstructive sleep apnea and risk of cardiovascular events and all-cause mortality: a decade-long historical cohort study. PLoS Med. 2014; 11: el001599.

[26] Li K, Wei P, Qin Y, et al. Is C-reactive protein a marker of obstructive sleep apnea? A meta-analysis. Medicine (Baltimore) 2017; 96: e6850.

[27] Horváth P, Lázár Z, Gálffy G, et al. Circulating P-selectin glycoprotein ligand 1 and $\mathrm{P}$-selectin levels in obstructive sleep apnea patients. Lung 2020; 198: 173-179.

[28] Horváth P, Tárnoki DL, Tárnoki ÁD, et al. Complement system activation in obstructive sleep apnea. J Sleep Res. 2018; 27: e12674.
(Bikov András dr., Budapest, Tömő u. 25-29., 1083 e-mail: andras.bikov@gmail.com)

Az Orvosi Hetilap 2020, 161, 1896. oldalán (44. szám) megjelent OH-Kvízre két helyes megfejtés érkezett.

A beküldök: Dr. Kónya Csaba (Budapest) és Dr. Somogyi Erzsébet (Budapest).

A nyerteseknek szívböl gratulálunk.

A nyereményüket - egy, az Akadémiai Kiadó webáruházában kedvezményes vásárlásra jogosító kupont - e-mailen küldjük el.

A cikk a Creative Commons Attribution 4.0 International License (https://creativecommons.org/licenses/by/4.0/) feltételei szerint publikált Open Access közlemény, melynek szellemében a cikk bármilyen médiumban szabadon felhasználható, megosztható és újraközölhető, feltéve, hogy az eredeti szerző és a közlés helye, illetve a CC License linkje és az esetlegesen végrehajtott módosítások feltüntetésre kerülnek. (SID_1) 